\title{
The Appraisal of the Teacher's Talk to Enhance Students' Critical Thinking Skills through Narrative Text in Design Thinking Pedagogy
}

\author{
Inggy Yuliani Pribady
}

\author{
SMP Negeri Bandung, Kota Bandung \\ inggyyuliani@gmail.com
}

Article History: Submitted 21 ${ }^{\text {st }}$ November 2018; Accepted 28 November 2018; Published 31 December 2018

\begin{abstract}
Design thinking has become a new trend at schools in different countries. There are many educators who are eager to adopt Design thinking as an effective strategy for helping their students to learn through solving real-world problems. For Indonesian context, Design Thinking provides a new innovative ground of teaching English in EFL setting. Teachers engage the students in collaborative problem solving, creative challenge, and foster social -emotional balance and stability. The paper portrays how the teacher conducts learning activities in the Empathy stage of Design Thinking to build students' critical literacy from the start. The attitude domain of the appraisal theory is used to disclose the way of the teacher to guide the students to express their emotional reaction toward the story, to assess the behavior of the characters and construe the value of things in the text. The classroom discourse analysis shows that the teacher's talk by employing the attitude resources plays important role in supporting the students to develop their critical thinking capacity and build their narrative's content knowledge. The result of the study is expected to enrich the reference of appraisal discourse analysis theory and provide the example of the teaching practice for enhancing students' critical thinking capacity in Narrative learning through Design Thinking pedagogy.
\end{abstract}

Keywords: appraisal analysis; critical thinking; narrative; design thinking

\begin{abstract}
Abstrak. Design thinking telah menjadi tren baru di sekolah-sekolah di berbagai negara. Para pendidik terpacu untuk mengadopsi Design Thinking sebagai suatu strategi yang efektif untuk membantu siswa mereka belajar dengan cara memecahkan masalah- masalah dunia nyata. Dalam konteks Indonesia, Design Thinking menyediakan dasar pengajaran Bahasa Inggris inovatif yang baru untuk EFL atau Bahasa Inggris sebagai bahasa asing. Guru melibatkan para siswa untuk bekerja sama memecahkan masalah, menyelesaikan tantangan dengan kreatif, meningkatkan stabilitas dan keseimbangan social dan emosional. Artikel ini menggambarkan bagaimana guru melaksanakan aktifitas pembelajaran di dalam tahap Empathy dari Design Thinking untuk membangun pengetahuan literasi kritis siswa dari awal. Domain Attitude dari teori Appraisal digunakan untuk mengevaluasi bagaimana cara guru untuk membimbing siswa di dalam mengekspresikan reaksi emosionalnya terhadap suatu cerita, untuk menilai tindak tanduk karakter-karakter di dalam cerita dan mengungkapkan nilai dari sesuatu hal yang terdapat di dalam teks. Analis wacana kelas akan memperlihatkan bagaimana guru bertutur dengan menggunakan sumber-sumber bahasa dari Attitude dapat memegang peranan yang penting untuk mendorong siswa agar dapat mengembangkan kapasitas berpikir kritis sekaligus membangun pengetahuan konten Narrative mereka. Hasil dari penelitian ini diharapakan dapat memperkaya referensi analisis wacana teori Appraisal dan menyediakan contoh praktik mengajar untuk meningkatkan kapasitas berpikir siswa di dalam pembelajaran Narrative melalui pedagogi Design Thinking.
\end{abstract}

Kata kunci: analisis Appraisal, berpikir kritis, naratif, design thinking 


\section{INTRODUCTION}

Teacher talk plays an important role to facilitate learning and promote communicative interaction in the classroom. The classroom interaction is better to be used to develop thinking rather than just to check understanding. Through this way, teachers will use language to engage the students into learning process in seeking of knowledge as well as to develop their thinking skills. The teaching of thinking skills is important to prepare the students to be able to struggle in a very competitive world in $21^{\text {st }}$ century. Thus, it is clear that English teachers' responsibility nowadays is not only teaching the students about the language but also how to learn through language. It is as proposed by Halliday's (1993) that children "learn language, learn through language and learn about language." Teachers, then, have to set out a sequence of learning experience to support the students in developing new understanding and thinking skills.

Teaching critical thinking skills has been a growing trend in language education in Indonesia for over 10 years since its importance to develop a much more critical and independent community has been widely recognized (Emilia, 2010). It is also clearly stated at the 2013 Indonesia Curriculum that the process of learning should be critical to develop students' potentiality to be able to think reflectively for the social problem solving in society and to develop a better democratic society life (Government Rule No. 22/2016).

Therefore, it is urgently needed that the process of teaching should embed the critical thinker components into learning. The central component of critical thinking is the reason assessment component. The critical thinker must be able to assess reasons and their ability to warrant belief, claims and actions properly. Besides, a critical thinker must have welldeveloped attitudes, dispositions, habits of mind, and traits of characters based on the reasons conception of critical thinking (Siegel, 1988: 39-410).

A Design-Thinking considered as an appropriate approach to embed the components of critical thinking into teaching through the design thinking stage of learning. Design Thinking is considered as the most effective strategy for helping the students to learn through technology, encourage and value critical reflection, identify and find solutions through independent and interdependent participatory (Wells, 2013). The design thinking process will engage students to construct new ideas, and use feedback to improve the ideas. It focuses on understanding a problem and finding a solution using empathy, define, ideate, prototype, and test. These five steps are the methodology that can be applied to the course and become drivers of integrating technology rich learning experiences into any subjects, including English (Brown, 2008).

This model of teaching is useful not only to help students to construct understanding but also to engage them in higher order thinking process. It is corresponding to the demand of the 2013 Indonesian Curriculum of the need to teach critical thinking skills. It is stated that the students are expected to have the thinking skills and should be: a. creative b. productive, critical, independent, collaborative and communicative (Government Rule No.22/2016).

The study is interested in looking at how a teacher conduct the process of learning at the stage of empathy in Design Thinking to develop students' critical thinking as well as the knowledge of the topic. This study will highlight the ways in which students participated in the classroom design activities by adopting the discourse of design in varied ways guided by the teacher. Students are engaged to explore all aspects of problems through multiple 
sources and iterations in a collaborative task and learn from different voices in collaborative efforts.

Narrative text is chosen in this study as suggested by Christie and Derewianka (2008: 31) that Narrative is a very privileged text in English to give the children opportunity to articulate values, attitude and belief and it exposes the students continuously at home at and school. Teacher and students can explore a Narrative text that is challenging and stimulating. It is a rich source to facilitate critical thinking and communicative skill. The students can express their feelings and thought on the characters and content of the story.

In the process of Narrative learning, the classroom interaction between the teacher and students is analyzed based on the interpersonal dimension of speaking through Appraisal system of Attitude. Appraisal is an interpersonal system at the level of discourse semantics to articulate interpersonal meaning with two other systems, negotiation and involvement in the realization of tenor relations (Martin and White, 2005:34). It has to do with evaluating things, people's character and their feelings, making judgment, making comments and reactions (Martin and Rose, 2008:31).

Appraisal system of attitude dimension will be used to see how the teacher is able to use the linguistics tools of attitude dimension to help the students to construe their critical thinking capacity in learning Narrative text and how the students are able to employ appraisal resources to help them to achieve the purpose of learning.

The discussions above about the teacher's talk to guide the students to understand the content or the topic of the text and to help the students to express their critical thinking capacity by giving response to evaluate the text, in EFL/ESL context are remained few discovered. This research therefore hopes to fill this gap. Then, the fundamental questions that are arisen are:

1. How the teacher's talk in teaching Narrative in the Design Thinking stage of Empathy can enhance students' critical thinking skills?

2. How do students come to be able to reflect their critical thinking in Narrative learning in the perspective of appraisal system?

The objectives of the study are to:

1. analyze the attitudinal resources used by the teacher to disclose the way the teacher's talk enhance students' critical thinking skills in teaching Narrative in the Design Thinking stage of Empathy.

2. Analyze the attitudinal resources used by the students to discover the way they reflect their critical thinking in Narrative learning in the Design Thinking stage of Empathy.

The results of the study are expected to provide an illustration of the practice of the Design Thinking methodology to help students enhance their language competences and critical thinking capacity. Moreover, the use of engagement of appraisal system to analyze the multilingual classroom interaction can enrich the literature of discourse analysis. 
This paper will discuss about the appraisal analysis on how teacher's talk can lead the students to enhance their critical thinking skills in Narrative learning in Design Thinking methodology and the appraisal analysis on how students come to be able to construe their critical thinking in classroom interaction through a process of Narrative learning in Design Thinking. It is therefore important to look at the critical thinking theories, the characteristics of a Narrative genre, Design Thinking methodology and Appraisal framework.

\section{Critical Thinking}

Critical thinking is the general term given to a wide range of cognitive skills and intellectual dispositions needed to effectively identify, analyze and evaluate arguments and truth claims; to discover and overcome personal prejudices and biases; to formulate and present convincing reason in support of conclusions; and to make reasonable, intelligent decisions about what to believe and what to do (Bassham, et al., 2005:1). Theorized in this framework, it is said that thinking is the extraordinary process we use to solve problems, make intelligent decisions, achieve the goals that give our lives purpose, and connect us to the people in our world (Chaffee, 2000: 5). There are four dimensions of critical thinking skills according to Mueller (2009:7):

1. Skills related to interacting with others in the world

2. Skills related to thinking about the world

3. Skills related to adapting to the world

4. Skills related to solving problems in the world.

There are numerous benefits that can be gained after mastering these critical thinking skills including better control of one's self, effective problem solving abilities, capability to think clearly, rationally and systematically, the ability to analyze information and empathy for other points of view. As stated by Chaffee (2000:45) that being critical means to question, to make sense of, to be able to analyze. It is by questioning, making sense of situations, and analyzing issues that we examine our thinking and thinking of others.

Reichenbach (2001:15) proposes that communicating with others by giving reason to our point of view and developing empathy to understand other people's experience and point of view is important. Critical thinking does not only solely gain insight into what we feel but also appreciate for the thoughts of others with open minded. Chaffee (2000: 69) argues that the best way to expand one's thinking and compensate for the bias that we all have is to discuss our experiences with other people. This is the way in which thinking develops by being open to the viewpoints of others and being willing to listen and to exchange ideas with them. From this point of view, it can be argued that becoming critical thinkers should primarily be interested in arguments and whether they succeed in providing us with good reasons for acting or believing (Bowell and Kemp, 2005: 2). The critical thinker must have a good understanding or the ability for assessing or providing reasons (Siegel, 1988:34).

In sum, Critical thinking requires self-knowledge, concentration, mental discipline, respect for others, awareness of fallacious reasoning, sensitivity to language, and, above all, a willingness to look carefully at arguments and to base evaluations on standards and criteria (Bassham, et al., 2005: 426).

Thus, teachers should teach their students to formulate opinions and draw their own conclusions, being wide open to other viewpoints and opinions, and then see the 
connections between the ideas. In this sense of thinking, in classroom interaction, the teachers are not only need to stimulate the students to express their opinions but also to motivate them to think about their ideas and the arguments that are proposed by others.

Teachers' role in integrating critical thinking into teaching is very important to accomplish an engaging classroom that will help students to improve their critical thinking skills so they will be succeed in their class, school and in life. Therefore, teachers have to masterfully apply a range of strategies to make the students can enjoy English language learning and give the students opportunities to develop their critical thinking skills.

Teachers' talk strategies can be used to lead the students to get more involved in the learning and allow them to express their own thinking. As stated by Hammond (2001:1213) that through talk, information and ideas can be shared, points of view explored, and explanations presented. In the process, the ways of thinking and understanding maybe constructed. In other words, it can be said that teacher talk in the process of learning provides learners with an interactive discourse that leads to negotiate meaning.

Relating that issue, Gibbons (1991) states that in talk where much learning occurs, the children are learn by talking, then teachers must create classroom situations where the children have opportunities to be confronted by viewpoint of others and allow them to discuss possible solution to a problem with their peers. In order to resolve disagreement, the children should be encouraged not only to justify their own position, but listen to and either accommodate or refute their opponent's. It can be concluded that, teachers take a role as the facilitator of learning to make sure that the classroom interaction is going well and all of the students are interactively engaged in searching of knowledge and expressing thinking. As Gibbons further (1991:29) says that the teacher will take responsibility for holding the discussion and controlling the turn taking to allow the learners to have the same opportunity to challenge and clarify thinking.

Regarding the role of talk in learning, Gibbons (2002:14) argues that it is to construct the resources for thinking. The learners are stimulated to think aloud. They are allowed to explore and clarify concepts or to try out a line of thought, through questioning, hypothesizing, making logical deductions and responding to other's ideas. But at the same time, classroom tasks must also provide the conditions that will foster second language development.

By this way, the students will gain a lot in learning. They are not only study about the linguistics aspects of a language but also develop their critical thinking skill and learn useful knowledge in a meaningful way

\section{Critical Thinking in Narrative Teaching}

This study is interested in looking at how a teacher encourage students to elaborate their voices and other viewpoints in first stage of Design thinking, empathy. It is to develop students' collaborative skills as well as the knowledge of the topic and how the students develop their critical thinking ability to have a point of view about the topic in a text. In the Empathy stage, students develop the empathy, understandings, experiences, insights and observations on the topic and the genre that they will use to build their design project.In this stage, teacher and students can explore a Narrative text to develop a deep and emotional understanding of their motivation, needs and problems. 
Through reading a narrative text, they will learn how to solve problems and the way to improve the aspects of lives as well as to gain an emphatic understanding of different personal characteristics. Feez \& Joyce (1998:31) stated that in reading Narrative, the readers usually want to work out the writer's point of view and decide whether they agree with it or not. They also have the power to judge the characters whether they are good or not, interesting or boring, cool or uncool, complex or simple.

Gibbons (1991:70) has similar statement, it is proposed that reading is the process of getting meaning from print. It is not passive, receptive activity, but requires the reader to be active and thinking. A competent reader reconstructs a writer's message. It is an interactive process between the reader and the text. To get the meaning from the text, readers bring their own background knowledge of the field and their understanding of the language system itself.

Therefore, the teacher, according to Christie (2005:99) should guide the children by teacher talk for dealing with written language. The teacher prepares the children for a reading the story by displaying the book revealing of its pictures. Guided talk can direct children initially to think about meanings in the story. Teachers' questions will guide comprehension and lead to later closer examination of the language patterns used. Children are asked to help identify the actual words in the text required to answer the questions.

Moreover, Christie and Derewianka (2008: 61) stated that learning to narrate about experience in talk prepares young children for narrating about experience in writing. The students are constantly exposed to the stories and they are asked to write as part of studying English and to express their attitude, values and belief. Then to add, Droga and Humphrey (2003: 64) stated that in Narrative learning, students are guided to use particular types of vocabulary to express feelings to build empathy and suspense in stories, making moral judgments of people's behavior, and assessing the quality of objects

In teaching Narrative text, teachers should familiar with the characteristics of the text to understand how to construct sentences and paragraphs to achieve the effects needed to interest the readers. The aim is to be able to help the students to comprehend the text effectively both in form and in content and to respond correctly to the students' writing and speech. The narrative unique features and conventions are as follows.

The purpose of Narrative is to entertain and instruct through dealing with unusual and unexpected development of events (Droga \& Humphrey, 2003:149). The schematic structure of Narrative begins with the orientation, then, the complication that is followed by an Evaluation, and is ended with a resolution and the last coda as being an optional stage for commentary (Droga \& Humphrey, 2003; Knapp \& Watkins, 2005; Christie, 2005; Christie \& Derewianka, 2008).

The linguistic features of Narrative according to Droga and Humphrey (2003:149):

1. Use of particular nouns to refer to the central characters, objects and places

2. Use of detailed noun groups to describe features or characteristics, incorporating a range of adverbials to build descriptions

3. Use of action verbs (usually past tense) to indicate activities and behaviors; characters often use saying and thinking verbs (i.e. direct or indirect speech / thought) 
4. Use of adverbials and dependent clauses to express important details such as time, place, extent, manner, etc.

5. Lexical cohesion achieved largely by synonyms, antonyms, collocations

6. Use of Affect, Judgment and Appreciation vocabulary to evaluate phenomena

7. Use of figurative language such as simile, metaphor, personification, alliteration, a typical word combinations, 'invented' words, etc.

8. Use of grading vocabulary to intensify descriptions.

As discussed above, Narrative text is beneficial for sharing experiences, explaining values and deciding solutions of problems. The characteristics of narrative text are appropriate with Design Thinking. It is a methodology for solving problems that focuses on asking questions and listening with empathy to the needs of individuals and groups. Next, discussion will be on how narrative text and Design thinking can contribute to enhance students' critical thinking capacity.

\section{Design thinking methodology}

Design thinking has gained its popularity and become a buzzword at schools. At its best, design thinking incorporates effective teaching techniques such as self-directed inquiry and collaborative problem solving, and which are embedded with social-emotional learning curricula that emphasize interpersonal skills such as collaboration and empathy. The end result of a design-thinking project is a tangible product that is designed by the students.

Regarding the issue mentioned above, Koh, et all. (2015:6) state that design thinking highlights the normative and ethical aspects of knowledge creation and innovation that are particularly relevant to the sphere of education. In the twenty-first century, design thinking contributes to the educational task of preparing the young to meet the complex global challenges. Brown (2008) explains that design thinking is seen as a "powerful, effective, and broadly accessible" approach to impact innovation that can be integrated in business, education and other fields.

In educational contexts, design thinking skills can be learned through pedagogical approaches that involve problem-based learning, project-based learning and inquiry based learning in classroom activities. In English language learning, Design thinking is found to be effective to enhance language skills. Chahal (2013) in his research finds that Design Thinking is a great tool for teaching $21^{\text {st }}$ century skills in teaching writing through webbased instruction. It is successful to strengthen students' processing sills in the observation, analysis and critical thinking. Leverenz (2014) mentions that designing innovative solutioncanhelpclosethegapbetweenwritinginsideandoutsideofschoolandprepare

studentstoparticipate inafutureofwriting. Fredrickson (2017) argues that building an ESL program through design thinking is beneficial for student-centered program and suits the needs of diverse learners who lack of the language skills needed to access the curriculum.

Kern (2000:116-117) points out that the concept of design in reading is as a process by which a reader organizes/ designs the world. He explains further that in terms of design model, reading is a dynamic rhetorical process of generating meanings from text that draws on all of one's semiotic resources. A reader encounters a result of a particular act of design in every text. It encodes particular reader-writer relationships, and a particular framing of a real or imagined world. Readers try to understand this kind of relationship and its world by bringing their available design to the task of comprehending a text. 
Related to writing as design, Kern (2000:171) argues that writing involves the use of available design. It needs internalized residual voices and language forms, the knowledge of rhetorical and stylistic devices, genres, formatting conventions, etc. as resources in a dialogic negotiation between internal and external representation of meanings. Writing involves design process to generate new ideas, to experiment with reconfigurations of language and to create fictional words. Design also involves the processes of planning, drafting, revising, and editing.

\section{Design thinking teaching Cycle}

In reading and writing of Design-Thinking model, students use reading and writing skills to solve a challenging question or problem. This process encourages the development of systems thinking, as well as the development of literacy. The following is a model drawn upon Stanford University Institute of Design's Design Thinking by Ponet (2013) in KNILT (The Knowledge Network of Innovations in Learning and Teaching).

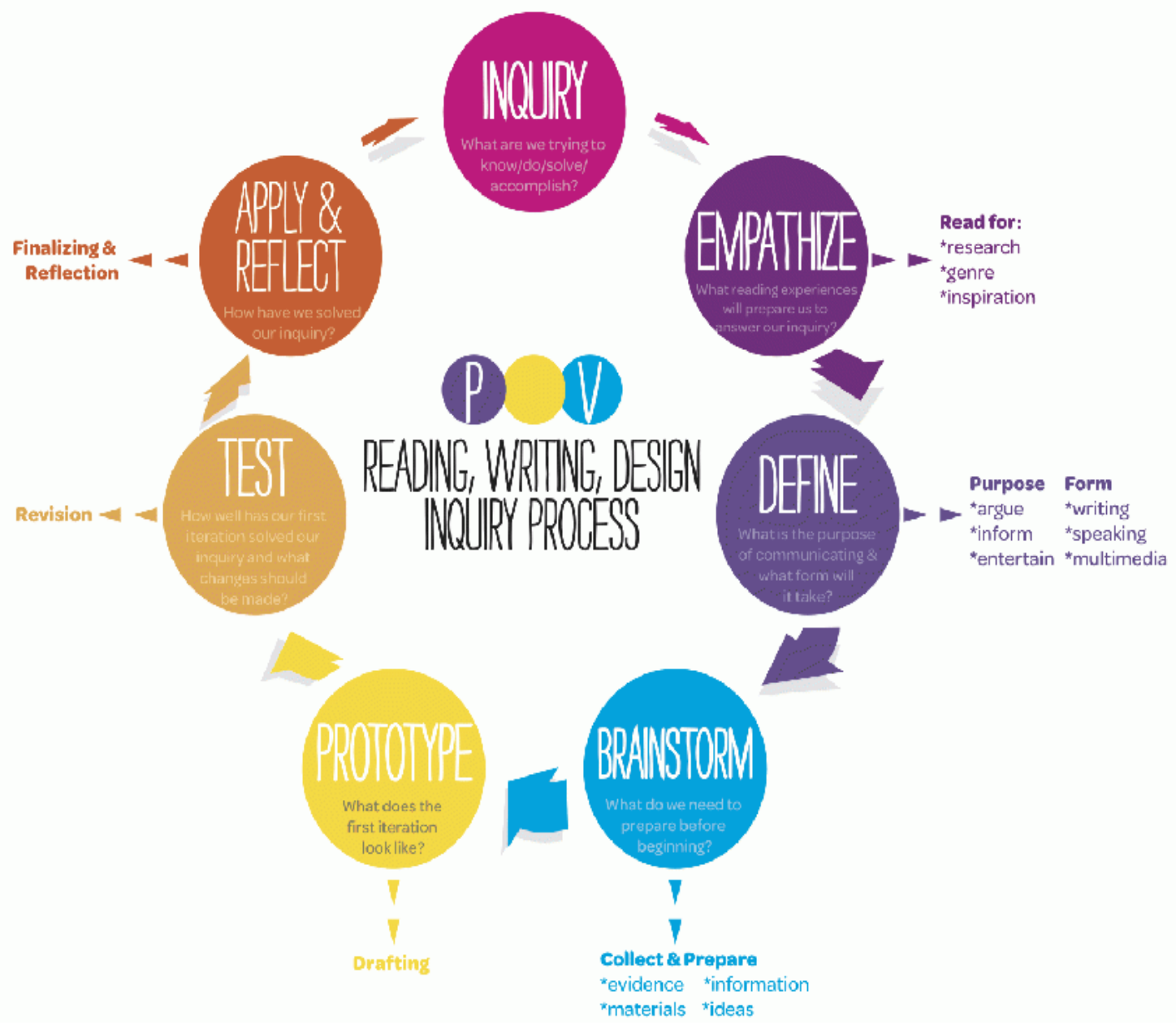

Students begin this process by empathizing, or forming a deep understanding of the topic, through reading and analyzing various texts, in order to build up research, inspiration, or understanding of a topic or genre. Students may empathize many times throughout a cycle. 
Then, students define the means and purpose of their communication, in order to prepare to brainstorm what needs to be collected, analyzed, and evaluated in order to begin writing or creating. Next, students pass through a series of prototypes, or drafts of their writing. They test to revise, edit, and refine their writing through various forms of teacher, peer, and self-evaluation. Finally, students apply their learning to solve the inquiry and reflect on their success in solving the inquiry.

Design thinking can be applied to any curriculum or subject. The following stage of design thinking for teaching literacy is adapted from Grodner (2013) which is almost the same with the previous stages.

\section{Empathy}

Prepare for and participate effectively in a range of conversations and collaborations with diverse partners, building on others' ideas and expressing their own clearly and persuasively.

Read closely to determine what the text says explicitly and to make logical inferences from it; cite specific textual evidence when writing or speaking to support conclusions drawn from the text. Reading skills are practiced during the Empathize stage.

\section{Brainstorm}

Students may practice speaking skills through collaboration, where students may do best to interact with others as they tease out their ideas.

\section{Define}

Produce clear and coherent writing in which the development, organization, and style are appropriate to task, purpose, and audience. The Define stage helps students to figure out how to make their communications appropriate for their task, purpose, and audience.

\section{Prototype}

Develop and strengthen writing as needed by planning, revising, editing, rewriting, or trying a new approach. In the Prototype stage, students develop and refine their writing through drafting.

\section{Test}

Demonstrate command of the conventions of Standard English grammar and usage when writing or speaking.

Demonstrate command of the conventions of Standard English capitalization, punctuation, and spelling when writing. Students can practice editing skills when they Test and revise their prototypes based on feedback.

\section{Apply and Reflect}

Present information, findings, and supporting evidence such that listeners can follow the line of reasoning and the organization, development, and style are appropriate to task, purpose, and audience. Make strategic use of digital media and visual displays of data to express information and enhance understanding of presentations. Adapt speech to a variety 
of contexts and communicative tasks, demonstrating command of formal English when indicated or appropriate.

The aim of the study is to analyze how a teacher by encourage students to elaborate their voices and other viewpoints in first stage of Design thinking, empathy. It is to develop students' collaborative skills as well as the knowledge of the topic and how the students develop their critical thinking ability to have a point of view about the topic in a text. In the Empathy stage, students develop the empathy, understandings, experiences, insights and observations on the topic and the genre that they will use to build the rest of the design project. The classroom interaction in the Empathy stage of Design thinking process between the teacher and students is analyzed based on the interpersonal dimension of speaking through Appraisal system of Engagement. It is used to see how the teacher is able to use the linguistics tools of attitude to help the students to construe their ideas and how the students are able to attitudinal resources to help them to strengthen their arguments by using the sources as well as to analyze others' opinions.

\section{Appraisal system of Attitude}

As has been discussed above, the study focuses on how students develop their language skills and how they come to be able to construe their critical thinking in learning Narrative text through a process of scaffolding. It is therefore important to discuss about the analysis tool to uncover what's really going on in the learning process. Appraisal system will be used to analyze the classroom interaction of attitude. The system is appropriate for this study because appraisal is concerned with evaluation - the kinds of attitudes that are negotiated in a text, the strength of the feelings involved and the ways in which values are sourced and readers aligned" (Martin and Rose: 2007).

Attitude domain of appraisal is concerned with our feelings, including emotional reactions, judgments of behavior and evaluation of things (Martin and White,2005:35). The system of attitude that can be seen below in Error! Reference source not found. 1 comprises three major sub-systems: polarity of the attitude (positive or negative), attitude type (affect, judgement or appreciation), and the realization of the attitude (inscribed or invoked). 


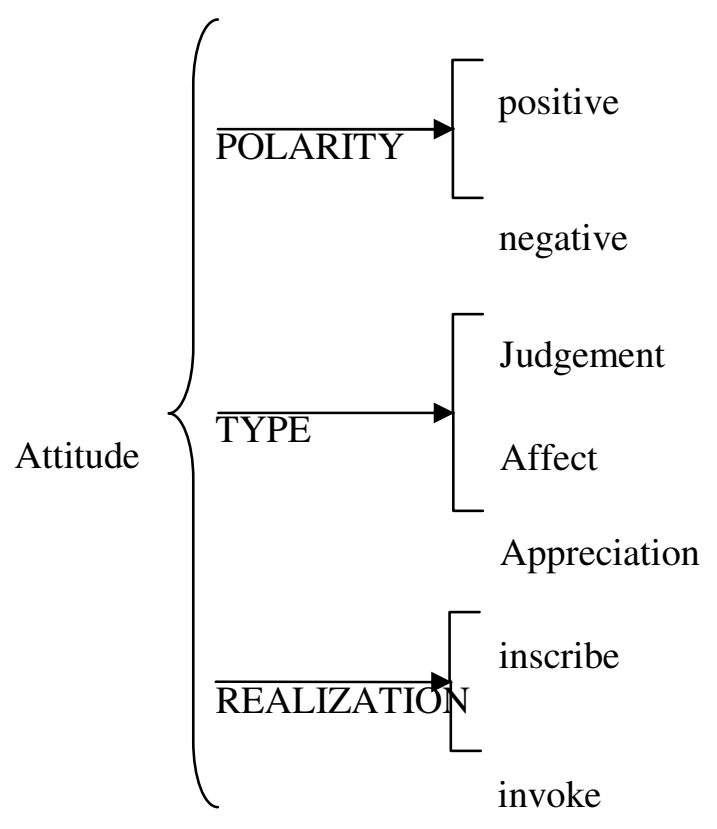

Figure 1 Appraisal system of attitude (Martin \& Rose:2007)

Attitude has a positive and negative dimension that corresponds to positive and negative evaluations of text and processes as the good and bad parameter (Christie and Martin:1997). For example 'He is happy', the adjective "happy" conveys a positive value. In contrast, in the clause "he is sad", the adjective "sad" carries a negative value.

There are three types of attitude: the first is affect as a resource for construing our feelings of happiness, inclination, security, and satisfaction. These feelings can be a surge of emotion (e.g. he laughs) or a continuous mental state (e.g. he is happy) Martin and White (2005: 45-52). The following example shows how the reaction is construed: I love reading the book because I like the suspense and mysterious story of the monarchy life.

Judgment is defined as an attitude resource for construing opinions and feelings about people and their behavior, norms about how people should and should not behave and can be further divided into two broad categories: social-esteem, and social sanction. Then, it is divided into five sub-types: judgment of esteem includes normality (i.e. how normal someone is), capacity (i.e. how capable someone is), and tenacity (i.e. how dependable someone is). Judgment of sanction concerns veracity (i.e. how credible someone is) and propriety (i.e. how moral someone is) (Martin and White, 2005:52-56). The following example illustrates the judgment: The evil witch is so immoral because she kills and tortures the innocent people for fun.

The third type of Attitude is appreciation for construing our evaluation of things (Martin and White, 2005: 56). The norms about how products, performances, and naturally occurring phenomena are valued. It is divided into three types: reaction, composition, and valuation. Reaction has to do with the degree to which the product, performance or natural phenomena in question captures our attention (reaction: impact) and the emotional impact it has on us (reaction: quality). Composition has to do with the perception of proportionality (composition: balance) and detail (composition: complexity) in a product, performance or natural phenomena. Valuation has to do with the assessment of the social 
significance of the product, performance or natural phenomena. The following example presents how appreciation is expressed: The plot of the story is consistent and engaging.

\section{METHOD}

This study was conducted at a government school located in West Java Province. The school was chosen because it is a potential source of rich data because of the fact that the school is a government institution with a good reputation to provide a context that is relevant to the study. It involved 30 ninth graders students and a teacher that had been teaching for 10 years. She was familiar with the SFL genre-based pedagogy. Since, only one class and one teacher with limited time of observation, the finding of the study therefore cannot be generalized due to the small sample of the study.

This study is qualitative and descriptive approach in nature. Qualitative approach was used to disclose attitudes resources that realized in classroom interaction talk. It is descriptive in the sense that this study is intended to describe the realization of interpersonal meaning in the talk based on Appraisal system as suggested by Martin \& White (2005). The unit of analysis is Appraisal device which focused on the realization of interpersonal meanings through words or phrases to express attitudes in the talk.

The data were collected through observations and recording of lesson carried out in the classroom. The teaching of three hours' lesson (3x40 minutes) in two meetings was observed and recorded. The recorded teacher talk and students' talk were transcribed according to the actual sequence of the teacher-students' interaction in the class. The interpersonal meaning constructed in the talk during the Narrative learning in the stage of Emphaty was analyzed based on the attitudinal resources (Affect, Judgement and Appreciation).

The procedure for analyzing attitude in the talk refers to system of analyzing attitude which is proposed by Martin \& White (2005:71-72). The steps are: identifying attitudinal categories (affect, judgement and appreciation), classifying each of the category in separate table, summarizing the attitudinal choice and interpreting it.

\section{RESULTS AND DISCUSSION}

The classroom talk was broken up into clauses to find out the source of attitude and what is being appraised (Martin \& White, 2005:71). Then they were analyzed to know what kind of attitude that is realized in the talk as well as the category of positive and negative attitude. The result based on the appraiser in the talk will be discussed follow. 


\section{Attitude in Teacher talk}

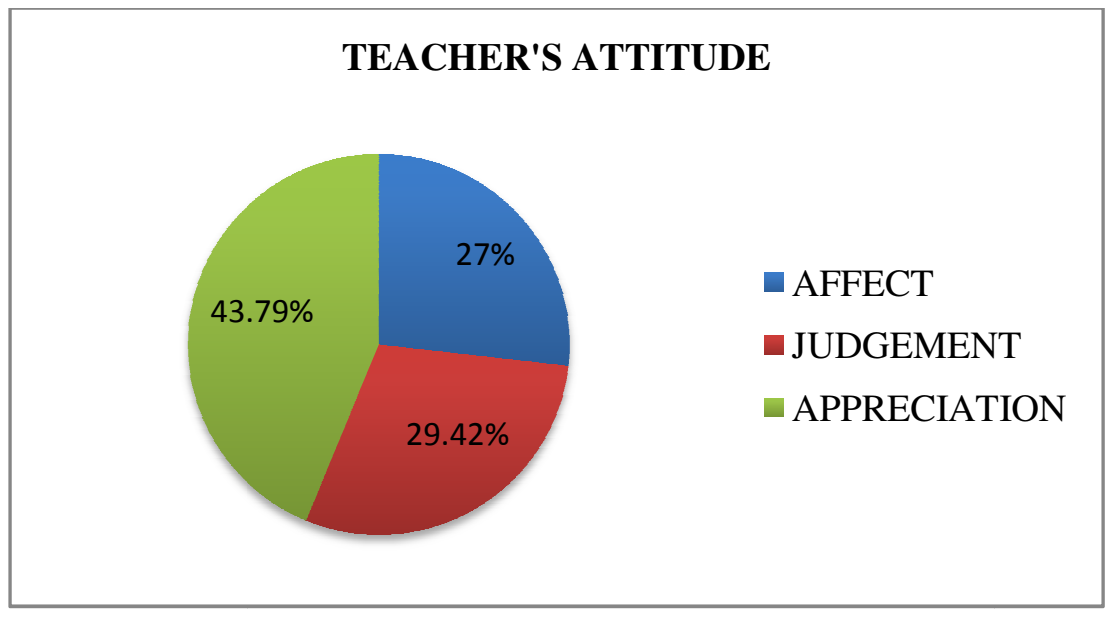

Figure 2 The total of Attitude Resources on teacher talk

The chart above illustrates the frequency of affect $27 \%$, judgement $29.42 \%$, and appreciation $43.79 \%$. The finding shows that the teacher mostly uses the attitude system of appreciation in her talk. It explicates that the teacher often uses the sub-system of appreciation as her tool in scaffolding to give her appreciation to students' answer. Most of the positive reaction is used to respond students' correct answers and the reaction is usually followed by positive feedback to motivate the students to speak up more. The following excerpt is presented how the teacher uses the positive reaction for appreciating students' answer:

Table 1 Classroom Excerpt Teacher's talk 1

\begin{tabular}{|c|c|c|}
\hline $21 \mathrm{a}$ & $\mathrm{T}$ & $\begin{array}{l}\text { OK, Now, Can you mention one of Narrative texts } \\
\text { that you know? }\end{array}$ \\
\hline $22 \mathrm{a}$ & S2 & Snow White \\
\hline $23 a$ & $\mathrm{~T}$ & $\begin{array}{l}\text { Snow white, good, I love the story, ... what do } \\
\text { you think about the story? }\end{array}$ \\
\hline
\end{tabular}

In this excerpt (23.a) the appreciation is realized through Adjective 'good'. The sentence implies that the teacher responds to a student correctly answer. It is used to confirm correctness by expressing that the teacher likes the answer.

On the other hand, the teacher uses the negative reaction to evaluate the character of the story based on what the students think of the character. The excerpt below shows that a student evaluates a character in local language and the teacher helps the student indirectly by confirming the answer in English.

Table 2 Classroom Excerpt Teacher's talk 2

\begin{tabular}{|l|l|l|}
\hline $116 \mathrm{~b}$ & S3 & He is handsome \\
\hline $117 \mathrm{~b}$ & S9 & Engga ...ih ... \\
\hline
\end{tabular}




\begin{tabular}{|c|c|c|}
\hline & & (Indonesian to English: No He is not) \\
\hline $118 \mathrm{~b}$ & S1 & $\begin{array}{l}\text { Asagorengheueuh ......bapanyamah } \\
\text { (Sundanese to English: he looks bad ... the father) }\end{array}$ \\
\hline 119 & SS & Laughing \\
\hline 120 & $\mathrm{~T}$ & $\begin{array}{l}\text { Well, he is not looking good in the picture, right? } \\
\text { Is that what you think? }\end{array}$ \\
\hline
\end{tabular}

By doing this, the teacher demonstrates and models a task as well as to provide relevant support to the students to make them to be able to handle a particular task by themselves (Gibbons, 2009: 32). The teacher also shows her good capacity in giving meaningful feedback for the students by praising their effort in solving the tasks. As stated by Mueller (2009:54-55) that practicing should be accompanied by meaningful feedback in order to be successful. However, the feedback should be targeted to the tasks rather than the person. The praise that are associated with the task can enhance students' desire for harder problem. On the other hand, the praise that is targeted to the characteristics will demotivate other students who are less.

Another negative category of appreciation that is found in teacher talk is Valuation. It is to give an evaluation whether the story is worth or not. The aim to give a model to the students on how to assess the quality of a story. The excerpt below will show how it is realized:

Table 3 Classroom Excerpt Teacher's talk 3

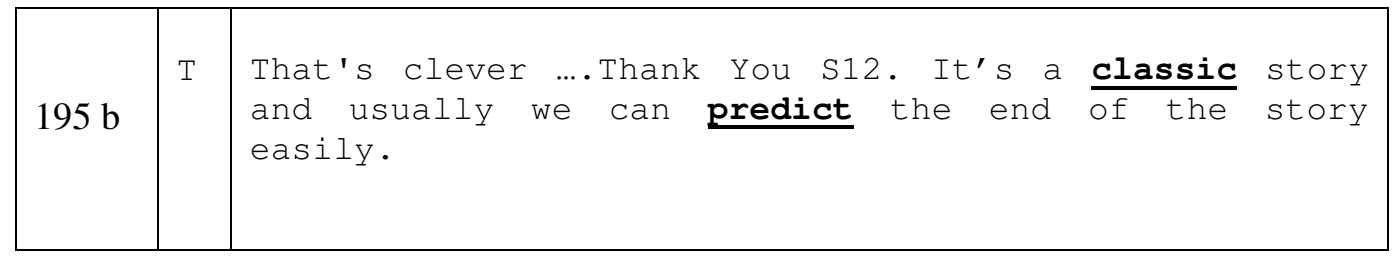

The second attitude system that is realized by the teacher in her talk is affect. Affect is expressed to describe negative or positive feelings towards the characters or the plots of the story. As Droga \& Humphrey (2003:65) stated that identifying the feelings of the characters is very important for involving readers and listeners in stories such as narratives and literary recounts. Affect allows readers and listeners to empathies with characters so that they care what happens to them as they go through extraordinary events. Let's see the excerpts below.

Table 4 Classroom Excerpt Teacher's talk 4

\begin{tabular}{|c|l|l|l|}
\hline $165 \mathrm{a}$ & $\mathrm{T}$ & Why Malinkundang is angry because of that? S5? \\
\hline $166 \mathrm{a}$ & $\mathrm{S} 5$ & He is shy cause her mother poor & \\
\hline $167 \mathrm{a}$ & $\mathrm{T}$ & $\begin{array}{l}\text { Yes ..... he is embarrassed because his mother is poor } \\
\text { What do you think of his mother face? Mmmmmmhh... } \\
\text { siapaya...yang belum....kamuyabelum...S11 }\end{array}$ \\
\hline
\end{tabular}




\begin{tabular}{|l|l|l|}
\hline $168 a$ & $\begin{array}{l}\text { S1 } \\
1\end{array}$ & Sad \\
\hline $169 a$ & T & Kenapa sad? \\
\hline $170 a$ & S1 & Dimarahi anaknya \\
\hline $171 a$ & T & Because her son is angry at her \\
\hline
\end{tabular}

In this case, the teacher tries to develop students' point of view and make them think of good reasons for that point of view. Affect is used as a source to develop independent thought. It is as argued by (Leicester \&Taylor, 2010:20-21) that a critical thinker involves reflecting on our own beliefs and viewpoints, giving reason for the point of view and develop empathy).

The teacher also develops the question model of inquiry to make the students to become curious about the world by posing meaningful questions about the content. However, in this excerpt, the teacher does not assign the students to develop questions from their own reading after she is modelling her own curiosities, as suggested by Barrel (2008:107) in Pressien (2008).

The last evaluative category that is used by the teacher is Judgement. The Expressions of Judgement are used to assess (positively or negatively) what people do, say or belief according to the value of particular institutions (Droga\& Humphrey, 2003:68). Below is the excerpt that shows the realization of Judgement in the talk:

Table 5 Classroom Excerpt Teacher's talk 5

\begin{tabular}{|c|c|c|}
\hline $90 a$ & $\mathrm{~T}$ & Do you know Thor? The movie? \\
\hline $91 \mathrm{a}$ & S7 & Yes \\
\hline $92 \mathrm{a}$ & $\mathrm{T}$ & Was he a brave man? \\
\hline $93 a$ & S 7 & Ya \\
\hline $94 a$ & $\mathrm{~T}$ & Why? \\
\hline $95 a$ & S7 & Because he not afraid to enemy \\
\hline $96 a$ & $\mathrm{~T}$ & $\begin{array}{l}\text { Thor was a brave man because he was not afraid when } \\
\text { he fought with his enemies }\end{array}$ \\
\hline $97 a$ & SS & Yesss... \\
\hline $98 a$ & $\mathrm{~T}$ & $\begin{array}{l}\text { Repeat me... Thor was a brave man because he was } \\
\text { not afraid when he fought with his enemies }\end{array}$ \\
\hline $99 a$ & S S & $\begin{array}{l}\text { Thor was a brave man because he was not afraid when } \\
\text { he fought with his enemies }\end{array}$ \\
\hline $100 \mathrm{a}$ & $\mathrm{T}$ & Now, S5, do you agree that Thor was a brave man? \\
\hline
\end{tabular}




\begin{tabular}{|l|l|l|}
\hline $101 \mathrm{a}$ & S5 & Yes, buuut .... \\
\hline $102 \mathrm{a}$ & $\mathrm{T}$ & What? Tell \\
\hline $103 \mathrm{a}$ & $\mathrm{S} 5$ & Maybe if his enemy very strong he afraid \\
\hline
\end{tabular}

It can be seen from the excerpt that the source of judgments is useful for the teacher to guide the students to judge a value and support it with a reason. At the same time, the teacher gives other students the opportunity to recognize good or poor evidence or reason that is expressed. It is to think whether the reason that is given by their friend is strong or weak. Leicester \&Taylor (2010:37) argue that in developing critical thinking it is important for the students to construct valid arguments and criticize flawed ones.

The teacher also uses Judgment to teach good behavior to students on how they should behave to other students or other people. The critical thinkers should learn all the time about values, strength of character and moral conduct through interactions and experiences with peers. They learn about keeping promises, lies and deception, and right and wrong behaviors. Caring behavior include helping friends and being compassionate. Bad behavior includes bullying, telling malicious lies and being unkind to others (Leicester \&Taylor, 2010:95).The excerpt below will give the illustration of the discussion aforementioned.

Table 6 Classroom Excerpt Teacher's talk 6

\begin{tabular}{|c|c|c|}
\hline $83 \mathrm{~b}$ & $\mathrm{~T}$ & $\begin{array}{l}\text { Ok S9 ... please go there and work with them ..... S6... don't } \\
\text { be rude to your friend... } \frac{\text { Please smile ....... we all friends }}{\ldots . \text { Semua temen ....ga boleh pilih pilih.... }} \\
\text { We have to kind and humble to other people. } \\
\text { Ingat itu ya ...please remember }\end{array}$ \\
\hline
\end{tabular}

In accordance with the discussion above, Mueller (2009:99-101) argues that it takes considerable time and effort to acquire such complex interpersonal skills. Teachers have to build it through: instruction and modelling, practice, feedback and reflection. Developing collaborative skills is to expressly describe and display them to the students. Then, give the students multiple opportunities in different context to apply the skills. After that, constructive feedback given by the teacher and peers is needed to track their progress. Finally, reflection is conducted to examine students' strengths and weaknesses to make them to be able to identify a goal to improve a particular skill. 


\section{Attitudinal Resources in Students talk}

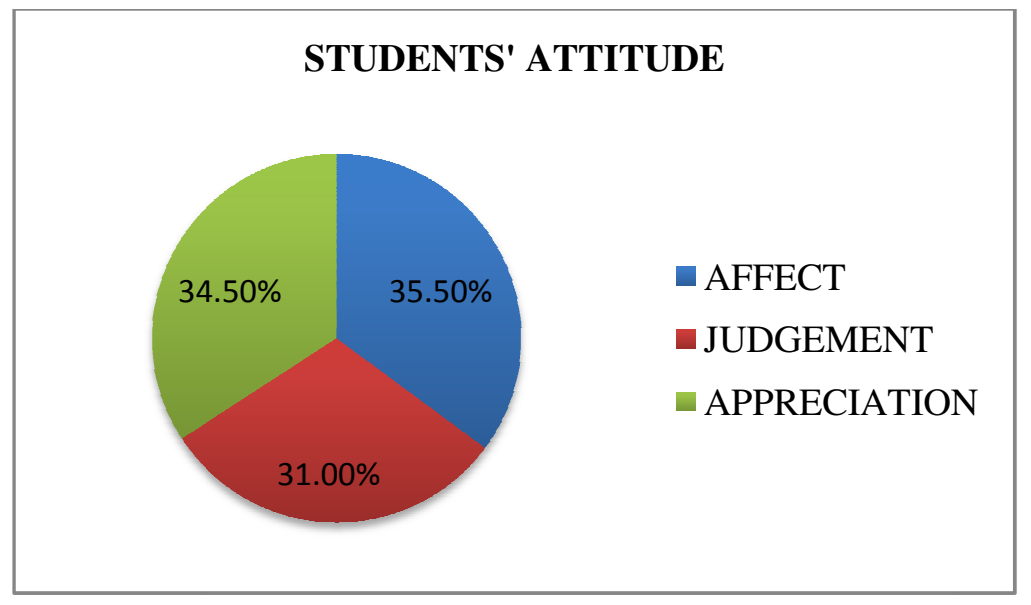

Figure 3 The Attitude Resources on Students talk

Affect and appreciation are mostly expressed the by the students in constructing interpersonal meaning. They have got the same frequency $34.50 \%$. The way Affect is realized in students talk can be seen from the excerpt below.

Table 7 Classroom Excerpt Students' talk 1

\begin{tabular}{|c|c|c|}
\hline $144 a$ & $\mathrm{~T}$ & $\begin{array}{l}\text { Yes ...what do you think of them? Are they best } \\
\text { friends or enemies... }\end{array}$ \\
\hline $145 \mathrm{a}$. & SS & Best friends \\
\hline $146 a$. & $\mathrm{T}$ & Why? Do you have any reason? \\
\hline $147 \mathrm{a}$. & S7 & They are happy \\
\hline $148 \mathrm{a}$. & $\mathrm{T}$ & Yes ...what else S5? \\
\hline $149 a$. & S5 & They are not fighting \\
\hline $150 a$. & $\mathrm{T}$ & Yes, you right .... what else s1? \\
\hline $151 \mathrm{a}$. & S1 & $\begin{array}{l}\text { They like each other, they are comfortable and live } \\
\text { together }\end{array}$ \\
\hline
\end{tabular}

The excerpt shows that the students use Affect to describe the character, the situation or actions in the story. The mood of the character can give the description of a scene in the story. The description can be used by the students to develop empathy to understand others' feeling. Reichenbach (2001:146) stated that descriptions play an important role to provide background data that critical thinkers can use in evaluation. It also can be seen that the students develop the critical thinking skill for interacting with others. They show their competent at interpersonal skills that is the abilities to take the perspective of others. The other critical thinking skills that is also shown is to make sense of the world by emerging the capacity of logic and reasoning to identify assumptions, the ability of analytical skills 
to identify the criteria for judging things and the last, the evaluation skills to evaluate claim and draw a conclusion (Mueller, 2009:8).

The sub domain Appreciation is used to describe the physical features of the characters, the scene, places and things. The following excerpt will present how it is realized.

Table 8 Classroom Excerpt Students' talk 2

\begin{tabular}{|c|c|c|}
\hline $114 \mathrm{a}$. & $\mathrm{T}$ & $\begin{array}{l}\text { Tell me ......do you have any idea? How does snow White } \\
\text { look like? }\end{array}$ \\
\hline $115 \mathrm{a}$. & SS & Pretty ....cantik....beautiful.... \\
\hline $116 \mathrm{a}$. & $\mathrm{T}$ & S8? Can you tell me \\
\hline $117 \mathrm{a}$. & S8 & She is pretty, her hair is beautiful, nice body... \\
\hline $118 \mathrm{a}$. & $\mathrm{T}$ & Why is she pretty and prefect? \\
\hline $119 a$. & S 8 & Cause she is a princess \\
\hline $120 \mathrm{a}$. & $\mathrm{T}$ & $\begin{array}{l}\text { are all the princess pretty and beautiful and have nice } \\
\text { figure of body? S4? }\end{array}$ \\
\hline $121 \mathrm{a}$. & S 4 & ...yes ...but ...maybe not... \\
\hline $122 \mathrm{a}$. & $\mathrm{T}$ & S1? \\
\hline $123 a$. & S1 & Hmmmmm ...maybe not all...some is ugly \\
\hline $124 \mathrm{a}$. & $\mathrm{T}$ & $\begin{array}{l}\text { Most of the princess in the story are beautiful and } \\
\text { pretty but maybe in reality not all of them are like } \\
\text { that.... }\end{array}$ \\
\hline
\end{tabular}

The above excerpt shows us that the students learn how to describe a character by talking about the physical appearance of it. By interacting with the teacher and other students, the students describe the quality of the character.It is one of the stages to apply critical thinking, by asking the students to discuss, express, or explain what they have read, heard or seen. This task also requires students to use a language to communicate what they know to others.Judging the characters and judging the story are conducted by the students through the last attitudinal sub domain of Judgement. The teacher and students use the sources of Judgement to explore ethical and moral problems.

It is important for the critical thinkers to think about wrong and moral goodness, and to try to work out on how to act in the right way, or to try to solve a moral dilemma, or having a critical reflection about it (Leicester \&Taylor, 2010:37). Let's see how it works at the class discussion in the excerpt below.

Table 9 Classroom Students' talk 3

\begin{tabular}{|c|l|l|l|}
\hline 53a. & S6 & About Tangkuban Perahu \\
\hline $54 a$. & T & $\begin{array}{l}\text { Yes .... Right...the legend of Tangkuban Perahu } \\
\text { Mountain...what else.... what do you know about the }\end{array}$ \\
\hline
\end{tabular}




\begin{tabular}{|c|c|c|}
\hline & & legend.... \\
\hline $55 a$. & SS & Silence ...... \\
\hline $56 a$. & $\mathrm{T}$ & S2, what do you know? \\
\hline $57 a$. & S2 & A boy love his mother. It is not normal \\
\hline $58 a$. & $\mathrm{T}$ & $\begin{array}{l}\text { Ya .... it is an odd story ... what do you have in your } \\
\text { mind? Is it ok if a boy loves his own mom? }\end{array}$ \\
\hline $59 a$. & SS & Noo00000... . \\
\hline $60 a$. & $\mathrm{T}$ & Why? Why No? \\
\hline $61 \mathrm{a}$. & S3 & Haram ...atuh... \\
\hline $62 \mathrm{a}$. & $\mathrm{T}$ & Yes ...S3 ...it is immoral.... Why is it bad? S3? \\
\hline $63 a$. & S3 & Uuumhhh... cause ...of religion...it is wrong ... a sin \\
\hline $64 a$. & $\mathrm{T}$ & It is not allowed by our religion, by our belief \\
\hline $65 a$. & S3 & Ya ...itu ...bu .... \\
\hline $66 a$. & $\mathrm{T}$ & $\begin{array}{l}\text { How about you s1? Do you agree with } \mathrm{S3} \text { opinion? What } \\
\text { else? What is the other reason? }\end{array}$ \\
\hline $67 \mathrm{a}$. & S 1 & Yes ...Allahnot like it. It is insane \\
\hline $68 a$. & $\mathrm{T}$ & $\begin{array}{l}\text { True ... S1... Allah dislikes it .....it's against the rules } \\
\text { of God .... What else? What is the other reason? Do you } \\
\text { think that our society will accept it? }\end{array}$ \\
\hline $69 a$. & $\mathrm{S} 1$ & No... . people will reject it \\
\hline $70 a$. & $\mathrm{T}$ & $\begin{array}{l}\text { Of course Not } \quad \text { ya... because it is against the } \\
\text { norms....right ? }\end{array}$ \\
\hline
\end{tabular}

\section{CONCLUSION}

This study reveals that the resources of interpersonal language in attitude dimension of appraisal are useful to explore students' critical thinking capacity. The attitudinal resources are used to facilitate learning to help the students to gain new understanding and knowledge. It is realized through teacher talk to guide the students to understand, praise, assess, evaluate and judge a Narrative text. The talk is developed around the specific background knowledge of a Narrative text. The students are engaged in the learning to develop their thinking, sensing and feeling.

The students build up their knowledge and critical thinking capacity with the teacher's guidance. They gain their understanding on how to use the language with the help from the 
teacher. The resources of Affect, Judgement and Appreciation are used by the students to express their feeling, thought and evaluation.

However, the teacher should consider giving more time for the students to develop questions. The teacher had spent most of the time for questioning students. As stated by Chaffee (2000:45) that being critical means to question, to make sense of, to be able to analyze. It is by questioning, making sense of situations, and analyzing issues that we examine our thinking and thinking of others.

\section{REFERENCES}

Barrel, J.(2008).Did you ask a good question today inPressien, B.Z.(eds). (2008). Teaching for intelligence. $\left(2^{\text {nd }}\right.$ Edn).(Pp.101-110). California: Corwin Press a Sage Company. john barrel. Did you ask a good question today.

Bassham, G., Irwin, W., Nardone, H., and Wallace J.M. (2005).Critical thinking.A student's introduction.( ${ }^{\text {nd }}$ Edn.). New York: McGraw Hill.

Bowell, T and Kemp, G. (2005).Critical thinking and a concise guide.(2 ${ }^{\text {nd }}$ Edn.).New York: Routledge.

Brown, T. (2008). Design Thinking.Harvard Business Review, pp. 1-10.

Chafee, J. (2000). Thinking Critically.(6 ${ }^{\text {th }}$ Edn). Boston: Houghton Mifflin Company.

Chahal, M. (2013). Lesson writing: Innovations in problem designing.European Scientific Journal, Vol.9/17, pp. 163-170. ISSN: 1857-7431.

Christie, F. (2005).Language education in the primary years. London: Continuum.

Christie, F., and Derewianka, B. (2008). School discourse. London: Continuum.

Christie, F. and Martin, J. R. (eds). (1997). Genre and Institutions: Social Processes in the Workplace and School. London: Cassell.

Droga, L., \& Humphrey,S. (2003). Grammar and meaning. An introduction for primary teachers. Berry, NSW: Target Texts.

Emilia, E. (2010). Teaching writing.Developing critical learners. Bandung: Rizqi Press.

Feez, S., and Joyce, H. (1998).Writing skills.Narrative and nonfiction text types. Melbourne: Phoenix Education Pty. Ltd.

Fredrickson, C. (2017).Design thinking in ESL Programming: Creating A Program Model for newcomer students. School of Education Student Capstone Projects, 59, pp. 153. https://digitalcommpms.hamline.edu_cp/59. 
Gibbons, P. (1991).Learning to learn in second language.NSW:Primary English teaching Association.

Gibbons, P. (2002). Scaffolding language and scaffolding learning. Teaching second language learners in the mainstream classroom.Pourthsmouth, $\mathrm{NH}: H e i n e m a n$.

Gibbons, P.(2009). English Learners Academic Literacy and Thinking.Portsmouth, NH: Heinemann.

Halliday, M.A.K (1993). Towards a language based theory of learning. Linguistics and Education.5, pp. 93-116.

Hammond, J.(eds). (2001).Scaffolding teaching and learning in language and literacy education. Sydney: Primary English teaching association

Kern, R. (2000). Literacy and language teaching. New York: Oxford University Press.

Knap, P and Watkins, M.(2005). Genre, Text, Grammar. Technologies for teaching and assessing writing.Sydney: UNSW press.

Koh, J. H. L., Chai, C. S., Wong, B., \& Hong, H. Y. (2015). Design thinking and in-service teachers. In Design Thinking for Education, pp. 87-107. Singapore: Springer Singapore.

Leicester, M and Taylor, D. (2010).Critical thinking across the curriculum.Developing critical thinking skills, literacy and philosophy in the primary classroom.Bershire: McGraw Hill Companies.

Leverenz, C.S.(2014). Design thinking and the wicked problems of teaching writing. Computers and Composition, Vol. 33, pp. 1-12. doi: 10.1016/j.compcom.2014.07.001.

Martin, J.R., and Rose, D. (2007). Working with Discourse: meaning beyond the clause. $\left(2^{\text {nd }}\right.$ Edn.). London: Continuum

Martin, J. R., and Rose, D. (2008).Genre Relations.Mapping Culture. London: Equinox.

Martin, J.R. \& White P.R.R. (2005). TheLanguage of Evaluation: Appraisal in English. New York: Palgrave MacMillan.

MenteriPendidikandanKebudayaanRepublikIndonesia.2016.SalinanLampiranPeraturanMe nteriPendidikandanKebudayaan No. 22 tahun 2016 tentangStandar Proses PendidikandanMenengah. KementerianPendidikandanKebudayaan: Jakarta.

Mueller, J.(2009). Assesssing Critical skills. Ohio: Linworth Publishing, Inc.

Ponet, S. (2013).Using design thinking and inquiry in teaching literacy.The Knowledge Network for Innovations in Learning and Teaching (KNILT). Retrieved in 30 April 2018 from https://tccl.arcc.albany.edu/knilt/index.php/Using_DesignThinking_and_Inquiry_in_Teaching_Literacy. 
Reichhenbach, R.B.(2001).Introduction to Critical Thinking. New York:McGraw Hill.

Siegel, H.(1988). Educating reason.Rationality, critical thinking and education. New York: Routledge.

Wells, G. (1999). Dialogic inquiry.Towards a sociocultural practice and theory of education.Second Edition. Melbourne: Cambridge University Press. 